\title{
Üstün Yetenekli Öğrencilerin Küresel Salgın Sürecinde Ev Etkinlikleri, Okur Tepkileri ve Anlama Durumlarının Incelenmesi
}

\section{Examination of Gifted Students' Home Activities, Reader Responses and Comprehension during the Global Pandemic}

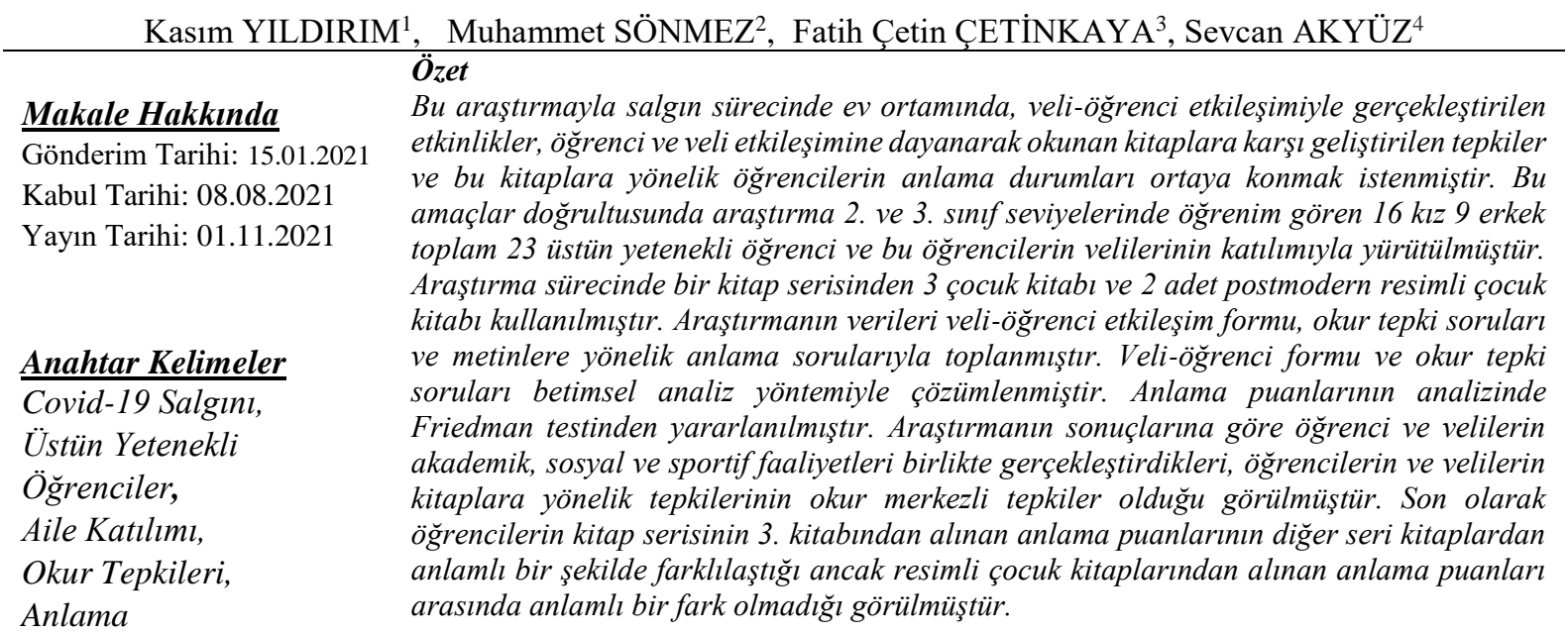

\section{$\underline{\text { Key Word }}$}

Covid-19 Pandemic,

Gifted Students,

Family Involvement,

Reader Response,

Comprehension

\begin{abstract}
With this research, it was aimed to reveal the activities carried out with parentstudent interaction in home-during the pandemic and to explore the reactions developed against the books read based on the student and parent interaction, and the students' level of comprehension towards these books. In line with these purposes, the study was conducted with the participation of 16 girls, 9 boys, a total of 23 gifted students and their parents who study at the 2nd and 3rd grades. In the research, 3 children's books from a book series and 2 children's books with postmodern pictures were used. The data of the study were collected parent-student interaction form, reader response questions, and comprehension questions for the texts. The parent-student interaction form and reader response questions were transformed into findings with the descriptive analysis method. Friedman test was used in the analysis of comprehension scores. According to the results of the research, it was revealed that students and parents carried out academic, social and sports activities together. In addition, it was observed that the reactions of students and parents to the books were reader-centered. Finally, it was seen that students' comprehension scores obtained from the third book of the book series differ significantly from other series books, but there was no significant difference between the comprehension scores obtained from the children's picture books.
\end{abstract}

Atıf için:

For Citation

Yıldırım, K., Sönmez, M., Çetinkaya, F. Ç., \& Akyüz, S. (2021). Üstün yetenekli öğrencilerin küresel salgın sürecinde ev etkinlikleri, okur tepkileri ve anlama durumlarının incelenmesi. Muğla Sıtkı Koçman Üniversitesi Ĕ̆itim Fakültesi [MSKU Journal of Education], 8(2), 690- 710 DOI: 10.21666/muefd.869258

\footnotetext{
${ }^{1}$ Muğla Sıtkı Koçman Üniversitesi, Eğitim Fak. , doğukanepsilon@gmail.com, ORCID: 0000-0003-1406-709X

${ }^{2}$ MEB, Hacı Seyit Taşan İlkokulu, muhammetsnmz41@ @mail.com, ORCID: 0000-0001-6516-7635

${ }^{3}$ Düzce Üniversitesi, Eğitim Fakültesi, fatihcetincetinkaya@ gmail.com, ORCID: 0000-0002-9843-6747

${ }^{4}$ MEB, Yalova Atatürk Bilim ve Sanat Merkezi, sevcanakyuz@gmail.com, ORCID: 0000-0001-9510-3851
} 
Çin'de başlayan ve sonrasında tüm dünyaya yayılan Covid-19 salgını yaklaşık olarak bir yıldan fazladır tüm dünyayı etkisi altına almıştır. Salgının olası etkilerini azaltmak için birçok alanda farklı uygulamalar ortaya konulmuştur. Eğitim-öğretim alanında alınan kararlardan öne çıkanı ise ülkelerin aldığı yüz yüze eğitim kısıtlamalarıdır. Bu karar eğitimle ilgili birçok paydaşı olumsuz etkilemiştir. İdareciler, öğretmenler, aileler çocuklar vb. eğitim sitemi içerisindeki tüm ögeler salgının getirmiş olduğu olumsuzluklardan farklı düzeylerde etkilenmiștir. Kısıtlama kararlarının ciddi öğrenme kayıplarına sebep olduğu düşünülmektedir. Bu öğrenme kayıpları okul öncesi, ilkokul, ortaokul gibi farklı kademelerde farklı düzeylerde gerçekleşebileceği gibi özel eğitimde de görüleceği öngörülmektedir. $\mathrm{Bu}$ araştırmanın odağını bir özel eğitim şekli olan üstün yetenekli öğrenciler oluşturmaktadır. Üstün yetenekli öğrencilerin yüz yüze eğitim kısıtlamaları sebebi ile okul yerine ev ortamında gerçekleştirmiş oldukları etkinlikler, anlama durumları ve okur tepkileri incelenmiştir. Aynı zamanda salgın sürecinde ki öğrenci-ebeveyn etkileşimi de ortaya konmaya çalışılmıştır.

Aralık 2019'da Çin'in Wuhan kentinde ortaya çıkan yeni tip koronavirüs hastalığı yaygın olarak koronavirüs şeklinde, hastalığa neden olan virüsün adıyla ise SARS-Cov-2 olarak tanımlanmıştır (He, Deng ve Lİ, 2020). Mart 2020'de Dünya Sağlık Örgütü koronavirüs hastalığını pandemi olarak ilan etmiştir (WHO, 2020a; 2020b). Salgının etkilerini azaltmak ve yayılmasını önlemek amacıyla tüm dünya genelinde birtakım önlemler alınmıştır. Alınan bu önlemler eğitim faaliyetlerini de etkilemiştir. UNESCO (2020) raporuna göre dünya genelinde 191 ülkede okullara ara verilmiş, yaklaşık 1,6 milyar öğrencinin eğitiminde kesinti yaşanmıştır. Yine UNESCO'ya (2020) göre Türkiye'de ilk ve orta düzeyde öğrenim gören yaklaşık 16,5 milyon öğrenci bu durumdan etkilenmiştir. Türkiye'de salgının eğitime olan etkilerini en aza indirmek ve eğitim faaliyetlerinin sürdürülebilirliğini sağlamak için uzaktan eğitim süreci başlatılmıştır. Bu süreçte Millî Eğitim Bakanlığı (MEB) tarafından oluşturulan Eğitim Bilişim Ağı (EBA) üzerinden eğitim faaliyetlerine devam edilmiştir. Uzaktan eğitim dönemi faaliyetleri başta çocuklar olmak üzere tüm aile fertlerini etkilemiştir (Başaran ve Aksoy, 2020). Salgın çocukların okul kurumundan uzaklaşıp daha önce herhangi bir uyum sürecinde yer almadan uzaktan eğitimle öğrenim görmeye başlamalarına neden olmuş, uzaktan eğitim sürecinden önce öğrencilerin okulda edindikleri kazanımlar ev ortamında çeşitli etkinliklerle zenginleştirilse de salgın döneminde yüz yüze eğitim olmadığı için evde yapılan çalışmalar öğrenmenin tek kaynağı hâline gelmiş̧tir (Çaykuş ve Mutlu Çaykuş, 2020).

Epstein (2011) ev ve okul ortamlarının çocuğun akademik gelişimi için örtüşen etki alanları oluşturduğunu aktarmaktadır. Ebeveynlerin çocukların öğrenimine katılması ilkokul döneminde çocukların okuldaki performansına olumlu katkı sağlamaktadır (Jeynes, 2005; Jeynes, 2007; Kaysıl1, 2008). Öğrenme firsatlarına önem veren, uyarıcı bir ortamında yetişen çocukların akademik anlamda daha başarılı olduklarını gösteren çok sayıda çalışma vardır (Örn, Jeynes, 2005; Van Steensel, 2006). Ebeveynlerin en kolay dâhil olabilecekleri alanlardan biri de okuryazarlık becerilerdir. Bir okuma materyali ile sürece dâhil olan ebeveyn çocuğun okuryazarlık becerilerinin gelişiminde fark oluşturur (Sénéchal \& LeFevre, 2002). Evde okuma etkinliklerinin okuma başarısı, okuma tutumu, okuma motivasyonu ve dil becerilerine önemli etkileri olduğu bilinmektedir (Clark ve Picton, 2012). Okumada yaşanan başarı, diğer alanlarda da başarılı olmaya açılan bir kapıdır (Jordan, Snow ve Porsche, 2000). Son 30 yılda ulusal ve uluslararası alanyazında ev ortamında ailenin katılımını inceleyen çalışmalara bakıldığında evde okuma çalışmalarının etkileri daha kolay anlaşılacaktır.

Rowe (1991) öğrencilerin okuma başarısını etkileyen ev geçmişi ve duyuşsal, davranışsal faktörleri açıklamayı amaçlayan çalışmasında ailenin sosyo-ekonomik durumu, yaşı ve cinsiyeti ne olursa olsun evde okuma etkinliklerinin öğrencilerin okuma başarısı ve okumaya yönelik tutumları üzerinde olumlu etkileri olduğu sonuçlarına ulaşmıştır. Faires, Nichols ve Rickelman (2000) yaptığı araştırmada ebeveyn katılımının birinci sınıf öğrencilerinin okuma seviyelerine katkısı olup olmadığını incelemiştir. Araştırma sonuçlarına göre ebeveyn katılımının öğrencilerin okuma durumlarına önemli katkıları olduğu ortaya çıkmıştır. Sénéchal ve LeFevre (2002) yaptıkları çalışmada erken ev okuryazarlık deneyimlerinin dil becerisi, okuryazarlık becerisi ve okuma başarısıyla olan ilişkisini incelemiştir. Araştırmanın sonuçlarında çocukların kitaplarla olan etkileşiminin kelime dağarcığı ve dinlediğini anlama becerileriyle ilişkili olduğu, aynı zamanda ebeveyn katılımının erken okuryazarlık becerilerini geliştirdiği ortaya çıkmıştır. Baker (2003) ev ortamı ve okuma motivasyonu üzerine yaptığı çalışmada, destekleyici ev ortamlarının okuma motivasyonunu artırdığı sonucuna ulaşmıştır. Buna bağlı olarak öğrencilerin gönüllü okumalar gerçekleştirmeye yönelerek, okumada başarılı olduğuna değinmektedir. 
Van Steensel (2006) çocukların ev okuryazarlık faaliyetleriyle ilkokulun ilk yıllarındaki okuryazarlık gelişimi arasındaki ilişkiyi incelemiştir. Araştırmanın sonunda ev okuryazarlık faaliyetlerinin birinci sınıftaki kelime dağarcığı ve ikinci sınıftaki genel okuduğunu anlama düzeyi üzerinde olumlu etkilere sahip olduğunu ortaya koymuştur. Galindo ve Sheldon (2012) tarafindan gerçekleştirilen okul ve aile katılımı arasındaki ilişkiyi inceleyen çalışmada ise aile katılımıyla okuma ve matematik becerileri arasında ciddi bir ilişki olduğu görülmüştür.

Türkiye'de yapılan çalışmalarda da benzer bulgular elde edilmiştir. Er ve Arıcı (2018) ailelerin okuma eğitimi konusunda bilinçlendirilmesinin öğrencilerin okuduğunu anlama ve okuma motivasyonları üzerindeki etkisini incelemiştir. Araştırmanın sonucunda okuma konusunda bilinçlendirilen ailelerin ögrencilerinin okuduğunu anlama ve okuma tutumlarını olumlu yönde etkiledikleri sonucuna ulaşılmıştır. Kıvrak ve Yıldırım (2020) öğretmenlerin gözünden ilkokul birinci sınıf öğrencilerinin okuma yazma öğrenme sürecine aile katımının etkisini incelemiştir. Çalışma sonuçlarına göre öğretmenlerin büyük bir kısmı, aile katılımıla birlikte öğrencilerin okuma ve yazma başarılarının yükseldiğini belirtmektedir. Bahsedilen çalışmaların yanı sıra ev ortamı ve aile desteğinin okumayla birlikte ele alındığı birçok çalışma ulusal ve uluslararası alanyazında yer almaktadır (örn, Can, Deniz ve Çeçen, 2016; Crosby, Rasisnki, Padak ve Yildirim, 2015; Jordon, Snow ve Porche 2000; Y1lmaz ve Çalışkan, 2017). Ancak ev ortamında veli-öğrenci etkileşimiyle okunan kitaplara yönelik öğrenci ve velilerin tepkilerini ortaya koyan herhangi bir çalışmaya rastlanmamıştır. Bu çalışmanın bir diğer amacı olan salgın sürecinde ev ortamındaki veli-öğrenci etkileşiminin nasıl gerçekleştiğini inceleyen çalışmalara rastlansa da (Mart ve Kesicioğlu, 2020) bu çalışmaların sayısı azdır.

Görüldügü üzere koronavirüs salgınıyla birlikte yüz yüze eğitime ara verilmesi ve uzaktan eğitim döneminin başlamasıyla birlikte ev ortamında ailenin katılımıyla gerçekleştirilen etkinliklerin önemi bir kez daha ortaya çıkmıştır. Bu araştırmayla salgın sürecinde ev ortamında veli-öğrenci etkileşimiyle gerçekleştirilen etkinlikler, öğrenci ve veli etkileşimine dayanarak okunan kitaplara karşı geliştirilen tepkiler ve bu kitaplara yönelik öğrencilerin anlama durumları ortaya konmak istenmiştir. Bu genel amaçlar doğrultusunda aşağıdaki sorulara cevap aranmıştır:

1.Korona virüs salgını sürecinde ev ortamında veli-öğrenci etkileşimiyle nasıl etkinlikler gerçekleştiriliyor?

2.Üstün yetenekli öğrencilerin ve bu öğrencilerin velilerinin seri kitaplara yönelik tepkileri nelerdir?

3.Üstün yetenekli öğrencilerin ve bu öğrencilerin velilerinin resimli çocuk kitaplarına yönelik tepkileri nelerdir?

4.Üstün yetenekli öğrencilerin okunan seri kitapları anlama durumları kitaplara göre farklılaşmakta midir?

5.Üstün yetenekli öğrencilerin okunan resimli çocuk kitapları anlama durumları kitaplara göre farklılaşmakta mıdır?

\section{Yöntem}

\section{Araştırmanın Modeli}

$\mathrm{Bu}$ araştırma nitel araştırma yöntemlerinden betimsel bir durum saptaması niteliğindedir. Durum çalışmaları bir olay ya da olgunun derinlemesine betimlenmesi ve incelmesi olarak ifade edilebilir (Merriam, 2009). Bu doğrultuda yaşanan salgın sürecinde üstün yetenekli öğrencilerin ev ortamında gerçekleştirmiş oldukları etkinlikler, anlama durumları ve okur tepkileri incelenmiştir. Bunun yanında salgın sürecindeki öğrenci-ebeveyn etkileşimi de ortaya konulmaya çalışılmıştır.

\section{Çalışma Grubu/Evren ve Örneklem}

Araştırmanın çalışma grubu araştırmaya katılmak için gönüllü olan16's1 erkek 9'u kız olmak üzere toplam 23 üstün yetenekli öğrenci ve bu öğrencilerin velilerinden oluşmuştur. Bu öğrencilerin 11'i 2 . sınıfta, 12'si ise 3. sınıfta öğrenim görmektedir. Toplam 14 öğrencinin 8 yaşında, 8 öğrencinin 9 yaşında ve 1 öğrencinin de 10 yaşında olduğu anlaşılmıştır. Öğrenci kardeş sayıları 0 ile 3 arasında değişiklik göstermektedir. 3 öğrencinin tek çocuk, 12 öğrencinin 1 kardeşi, 7 öğrencinin 2 kardeşi olduğu ve son olarak 1 öğrencinin 3 kardeşi olduğu görülmüştür. Öğrencilerin çoğunluğu ailesiyle birlikte yaşarken 1 öğrenci annesiyle (tek ebeveynli), 1 öğrenci de anneannesiyle yaşamaktadır. Araştırmaya katılan tüm öğrenciler resimli çocuk kitaplarıyla daha önce karşılaşmış durumdadırlar ve hepsinin evinde resimli çocuk kitapları bulunmaktadır. Velilerden edinilen bilgiler eşliğinde 13 öğrencinin günlük okuma 
çalışmaları yaptığı, 8 öğrencinin haftada birkaç kez okuma çalışmaları yaptığı, 2 öğrencinin ise haftada bir kez ya da daha az okuma çalışmaları yaptığı anlaşılmıştır.

13 öğrenci kitap okuma eylemini kendi isteğiyle gerçekleştirirken, 10 öğrenci daha çok dışsal güdülenme yoluyla kitap okumaktadırlar. Araştırmaya katılım gösteren 10 öğrenciye aile bireyleri tarafından sık sık sesli okuma yapılırken 12 öğrenciye ara sıra sesli okumalar yapılmakta; 1 öğrenciye ise sesli okuma yapılmadığı belirtilmiştir. Araştırmaya katılan öğrenci velilerinin yaşları ise 32 ile 51 arasında değişiklik göstermiştir. Öğrenci velilerini eğitim düzeyleri ilkokul ve lisansüstü eğitim arasında değişmektedir. 1 öğrencinin annesi ilkokul mezunu, 1 öğrencinin ise ortaokul mezunudur. Ancak genel anlamda ebeveyn öğrenim durumları yüksekokul, lisans ve lisansüstü şeklindedir.

\section{Araştırmada Kullanılan Resimli Çocuk Kitapları}

Araştırma sürecinde iki tür çocuk kitabı kullanılmıştır. Birinci tür seri kitap, ikinci tür ise postmodern resimli çocuk kitabıdır. Kullanılan seri çocuk kitapları 3 adettir. Bu kitaplar bir vakfin internet sitesinde yayınlanan kitap serisi içinden uzman görüşleri ile seçilen kitaplardır. 10 farklı seviyeye ait toplam 80 kitaptan oluşan kitap serisi içinden seçilen 3 kitap, serinin 7. seviyesine aittir. Kitaplar Zeynep Candır tarafından yazılıp, M.K Perker tarafından resimlenmiştir. Süreçte kullanılan postmodern resimli çocuk kitapları ise David Wiesner tarafından yazılıp resimlenmiştir. Bu süreçte David Wiesner'a ait Flotsam ve Anthony Browne ait Voices in the Park isimli kitaplar kullanılmıştır. Flotsam isimli kitap ilk olarak 2006 yılında Amerika Birleşik Devletleri'nde Clarion/Houghton Mifflin yayınevi tarafindan yayınlanmıştır. Bu kitap Caldecott Madalyası, Quill Award for Children's illustrated book gibi ödüllere layık görülmüş bir kitaptır. Voices in the Park isimli kitap ise ilk olarak 1998 yılında yayımlanmış ve Kurt Maschler Ödülünü (1998) kazanmıştır.

\section{Veri Toplama Araçları}

Araştırmanın verilerine ulaşılmak için 4 farklı veri toplama aracından yararlanılmıştır. Salgın sürecinin öğrenci-ebeveyn etkileşimine etkisini belirlemek için sınıf eğitimi alanında 3 uzman tarafından salgın süreci formu hazırlanmış, okunan resimli çocuk kitaplarına yönelik öğrencilerin okur tepkileri alınmış ve öğrencilerin anlama puanlarına ulaşılabilmek için ise anlama soruları kullanılmıştır. Aynı zamanda aile ve öğrencilerin demografik bilgilerini elde etmek için de demografik bilgi formu oluşturulmuştur. Araştırmada kullanılan resimli çocuk kitapları uzmanlar ve öğrencilerin sınıf öğretmeninin görüşleri alınarak belirlenmiştir.

\section{a) Öğrenci ve veli okur-tepki formu}

Okur tepkilerinin belirlenmesi için kullanılan form Hancock (2008) tarafından belirlenen sorulara göre hazırlanmıştır. Sorular oluşturulmadan önce kitaplar incelenmiş ve sorular dikkatli bir şekilde kitapların içeriklerine ve Honcock (2008) soru formatına uygun bir şekilde kitaplara göre uyarlanarak oluşturulmuştur. Bu form hem öğrenciler hem de veliler için aynı soruları içermektedir. Aşağıda her bir kitap için okur tepkilerini elde etmeye yönelik hazırlanan sorulara yer verilmiştir:

Yumurta Kırılırsa - Düğünde - Şanssız Balıkçılar Kitapları İçin;

1. Kerem ve ailesinin maceralarını anlatan bu kitapları okumak/dinlemek sana kendini nasıl hissettirdi? Kahramanlardan hangisinin yerinde olsan ne hissederdin? (Kerem, Zeynep, Emre, Murat) (Estetik Yönerge)

2. Bu kitapların kendi hayatınla veya tanıdığın biri ile ilgili hatırlattı̆̆ı bir şeyler var mı? Bizimle paylaşır misin? (Deneyimsel Yönerge)

3. Kerem ve ailesinin maceralarını anlatan bu kitaplarda senin için hangi mesajlar veya anlamlar var? (Yorumlayıcı Yönerge)

4. Eğer kitaptaki karakterlerden (Kerem, Zeynep, Emre, Murat) biri olmak isteseydin hangisini seçerdin ve neler yapmak isterdin veya o kahramana ne gibi tavsiyelerde bulunmak istersin? (Bilişsel Yönerge)

Flotsom Kitabı için;

1. Flotsam kitabını dinlemek/okumak sana kendini nasıl hissettirdi? Makineyi bulan çocuğun yerinde olsan ne hissederdin? (Estetik Yönerge)

2. Flotsam kitabının senin hayatınla veya tanıdığın biri ile ilgili hatırlattığı bir şeyler var mı? Bizimle paylaşır mısın? (Deneyimsel Yönerge)

3. Sence Flotsam kitabında senin için hangi mesajlar veya anlamlar var? (Yorumlayıcı Yönerge) 
4. Eğer kitaptaki karakterlerden biri olmak isteseydin hangisini seçerdin ve neler yapmak isterdin veya o kahramana ne gibi tavsiyelerde bulunmak istersin? (Bilişsel Yönerge)

Parktaki Sesler Kitabı için;

1. Parktaki Sesler kitabını dinlemek sana kendini nasıl hissettirdi? Kahramanlardan hangisinin yerinde olsan ne hissederdin? (Charles, Smudge, Charles'ın annesi, Smudge'nin babası) (Estetik Yönerge)

2. Parktaki Sesler kitabının senin hayatınla veya tanıdığın biri ile ilgili hatırlatığı bir şeyler var mı? Bizimle paylaşır mısın? (Deneyimsel Yönerge)

3. Sence Parktaki Sesler kitabında senin için hangi mesajlar veya anlamlar var? (Yorumlayıcı Yönerge)

4. Eğer kitaptaki karakterlerden biri olmak isteseydin hangisini seçerdin ve neler yapmak isterdin veya o kahramana ne gibi tavsiyelerde bulunmak istersin? (Charles, Smudge, Charles'in annesi, Smudge'nin babas1). (Bilişsel Yönerge)

\section{b) Demografik Bilgiler Formu}

Araştırmaya katılan öğrenci ve velilere ait bilgilere ulaşabilmek için demografik bilgi formu kullanılmıştır. Form içeriği hazırlanırken uzman görüşlerine başvurulmuştur. Formun tasarımı Google Formlar üzerinden gerçekleştirilmiştir. Form oluşturulma sürecinde önceden var olan okuma ve yazma ortamı demografik özelliklerini belirlemeye yönelik hazırlanmış formlar incelenmiştir. İncelenen formlar ve uzman görüşleri doğrultusunda yeni bir demografik bilgi formu oluşturulmuştur. Form sorularının 6 tanesi doğrudan öğrencilerin demografik özelliklerini öğrenmeyi amaçlamakta, 6 tanesi de velilerin demografik özeliklerini öğrenmeyi hedeflemektedir. Bunlara ek olarak öğrenci aile ortamının okuma arka planını ortaya koymak için geliştirilmiş 13 soruyla birlikte toplamda 23 soruyu içermektedir.

\section{c) Veli-Öğrenci Etkileşim Formu}

Salgın sürecinin öğrenci-ebeveyn etkileşimini nasıl etkilediğini ortaya koymak için oluşturulmuş bir formdur. Form uzman görüssleri doğrultusunda hazırlanmıştır. Form salgın sürecinin ev ortamında nasıl geçirildiği, öğrenciyi desteklemek için ne gibi aktiviteler yapıldığı, bu araştırmaya katılımın salgın sürecinde yaşananlara ne gibi etkileri olduğu gibi durumları belirlemeye yönelik 6 adet sorudan oluşmaktadır. Bu sorular yalnızca velilere yöneltilmek üzere hazırlanmıştır.

\section{d) Anlama Soruları}

Araştırmada kullanılan kitapların içerikleri incelenerek anlama soruları oluşturulmuştur. Her kitap için 5 adet anlama sorusu kullanılmıştır. Bu soruların 3 tanesi basit anlama düzeyindeyken 2 soru derinlemesine anlama sorularıdır. Anlama sorularının oluşturulma sürecinde hem seri hem de postmodern çocuk kitapları olan "Düğünde, Yumurta Kırılırsa, Şanssız Balıkçılar, Flatsom, Voices in the Park (Parktaki sesler)" kitapları incelenmiş uzman görüşleri doğrultusunda anlama soruları oluşturulmuş ve kullanılmıştır. Okunan kitaplar bağlamında hazırlanan anlama soruları alan uzmanlara gösterilmiş ve soruların anlama bağlamında benzer yapıları ölçtüğü noktasında dönütler alınmıştır.

\section{Verilerin Toplanması}

Veri toplama süreci, katılımcıların belirlenmesi, hazırlık ve uygulama aşamaları olmak üzere üç aşamada gerçekleşmiştir. Katılımcıların belirlemesi için veli izinlerine başvurulmuştur. Veli izinlerini alabilmek adına Google Formlar üzerinden araştırmanın amacının ve uygulama sürecinin detaylı bir şekilde anlatıldı̆̆ veli onam formu hazırlanmıştır. Hazırlanan formun linki WhatsApp uygulaması üzerinden velilerle paylaşılmıştır. Başlangıçta 26 veli ve öğrencinin katılımıyla yürütülmek istenen araştırma 3 velinin çalışmaya katılmak istememesi nedeniyle 23 öğrenci ve veliyle gerçekleştirilmiştir. Hazırlık aşamasında araştırmada kullanılacak kitaplar belirlenmiş ve araştırmanın veri toplama araçları oluşturulmuştur. Araştırmada kullanılacak kitaplar belirlenirken uzman görüşlerinden yararlanılmıştır. Bu bağlamda bir kitap serisine ait 3 adet kitap seçilmiş ve 2 adet de postmodern kitap kullanılmıştır. Belirlenen seri kitaplar Zeynep Candır ve M. K. Perker tarafindan kaleme alınan bir kitap serisi içinde yer alan "Düğünde, Yumurta Kırılırsa ve Şanssız Balıkçılar" isimli kitaplardır. Postmodern kitaplar ise "Voices in the Park ve Flatsom" kitaplarıdır. Postmodern metinler David Wiesener tarafindan kaleme alınıp resimlenmiştir. Araştırmanın salgın sürecinde gerçekleşmesi nedeniyle öğrenci ve velilerin sağlığını tehlikeye atmamak için kitapların öğrencilere elektronik ortamlardan ulaştırılmasına karar verilmiştir. Öncelikle kitapların sayfa sayfa resimleri çekilmiş daha sonra bu resimlerle Powerpoint dosyası oluşturulmuştur, kitaplar bütün halinde öğrenci ve velilere ulaştırılmak için hazırlanmıştır. 
Araştırmada kullanılan Voices in the Park kitabının metninin orijinal dili İngilizce olması nedeniyle kitap Türkçe çevirisi yapılarak kullanıma uygun hale getirilmiştir. Kitapların dil çevrileri için İngilizce dil eğitimcileri ve bu çalışmanın araştırmacıları birlikte çalışmışlar ve ortak bir karar doğrultusunda süreç tamamlanmıştır. Kullanılacak kitaplar belirlendikten ve kullanıma uygun hale getirildikten sonra araştırmanın veri toplama araçları oluşturulmuştur. Veri toplama araçları salgın süreci formu, anlama soruları, okur-tepki formu ve demografik bilgiler formu olmak üzere dört adettir. Salgın süreci formu, anlama soruları ve okur-tepki formu Word belgesi şeklinde hazırlanmıştır. Demografik bilgi formu ise Google Formlar üzerinden oluşturulmuştur. Araştırmanın hazırlık kısmı tamamlandıktan sonra uygulama basamağına geçilmiş̧ir.

Araştırmanın uygulama kısmında öğrenci velilerinin katılımcı olduğu bir WhatsApp grubu kurulmuştur. Daha önceden kullanıma hazırlanmış kitaplar ve Google Formlar üzerinden hazırlanan formların bağlantı linkleri bu grup üzerinden velilere ulaştırılmıştır. Kitaplar sırası ile “"Düğünde”, "Yumurta Kırılırsa", "Şansız Balıkçılar", "Voices in The Park", "Flotsam" şeklinde gruptan velilere ulaştırılmıştır. Her kitap okuma işlemi için bir günlük süre tanınmış ve birer gün arayla kitaplar grupta paylaşılmıştır. Kitap okuma işlemi veliler tarafından sesli bir şekilde gerçekleştirilmiş ve ögrenciler velilerin sesli okumalarını dinlemiştir. İki veli sesli okuma işleminin bilgisayar ekranından gerçekleştirildiğini belirtirken diğer velilerin tamamı okumaları telefondan gerçekleştirmiştir. Veliler her kitabın okuma işlemini gerçekleştirdikten sonra ilgili WhatsApp grubuna "okuduk" şeklinde dönüt sağlamıştır. "Okuduk" bilgisinden sonra sınıf öğretmeni okuduk bilgisini veren veliye özel mesaj aracılığı ile anlama sorularını göndermiştir. Öğrencilerin diğer öğrencilerin cevaplarını görmesinin önüne geçebilmek adına gelen cevaplarda özel mesaj aracılığıyla alınmıştır. Gelen cevaplar kayıt altına alınarak tüm kitaplar için süreç aynı şekilde devam ettirilmiştir. Tüm kitapların okuma işlemi tamamlandıktan sonra okur-tepki ve salgın süreci anketlerini içeren dosyalar grup aracılığı ile velilerle paylaşılmış ve cevaplar toplanıp kayıt altına alınmıştır. Salgın süreci anketleri yalnızca veliler tarafından cevaplanırken, okur tepki formları hem veli hem de öğrencilerin tepkilerini içermektedir. Yine demografik bilgiler formu da grupta paylaşılmak suretiyle velilere ulaştırılmıştır. Demografik bilgiler formuna gelen cevaplar Excel dosyasına aktarılıp kayıt altına alınmıştır. Katılımcı veli ve öğrencilerin tüm formlara cevap verip vermediği kontrol edilmiş, herhangi bir eksik veri olmadığına karar verilerek araştırmanın veri toplama süreci sonlandırılmıştır.

\section{Verilerin Analizi}

Velilerin görüşleri betimsel olarak analiz edilmiştir (1. araştırma sorusu). Yapılan analizler tablolaştırılıp örnek alıntılarla birlikte sunulmuştur. Alıntı işlemi için Veliler "V", öğrenciler "Ö" şeklinde kodlanmıştır. Okur tepkilerinin analizinde (2. ve 3. araştırma sorusu) öğrencilerden ve velilerden gelen cevaplar araştırmacılar tarafından tek tek okunmuştur. Öğrencilerin ve velilerin cevapları WollmanBonilla ve Werchadlo (1995) tarafından geliştirilen kategoriler kullanılarak analiz edilmiştir. Cevapların sıklık ve yüzdeleri hesaplanarak tablolar haline getirilmiştir. Wollman-Bonilla ve Werchadlo (1995) tarafından geliştirilen kategoriler şu şekildedir;

Metin merkezli cevaplar: Hikâyeyi yeniden anlatma, karakterleri anlama, soru sorma, tahmin etme Okur merkezli cevaplar: Kişisel tepki (düşünceler ve hisler), hikâye ile deneyimleri arasında bağlantı kurma, hikâyedeki olaylara katılma isteği

Öğrenci ve veli cevaplarının analiz edilmesi esnasında ana fikir belirlemeye yönelik cevaplar dikkat çekmiş ve Ulusoy'un (2016) çalışması temel alınarak metin merkezli cevaplar kısmına "ana fikirir" kategorisi eklenmiştir. Aynı zamanda cevapların ve kategorilerin tam olarak anlaşılması için örnek alıntılara yer verilmiştir. Demografik bilgiler formu analiz edilme sürecinde öncelikle Google formlar üzerinden alınan yanıtlar Exel dosyasına aktarılmıştır. Oluşturulan Exel formu soru başlıkları altında her bir öğrenci için değerlendirilerek öğrencilerin demografik bilgilerine ulaşılmıştır. Salgın süreci formu analiz edilirken her soruya gelen cevapların sıklıklarına ulaşılmıştır. Daha sonra gelen benzer cevaplar tek bir kategori altında toplanarak kategoriler oluşturulmuştur. Uygun kategoriler tek bir tabloda toplanmış, tablo başlı̆̆ kategorilere göre belirlenmiştir. Elde edilen kategorilerde cevapların ve tabloların daha net anlaşılması için örnek alıntılara yer verilmiştir. Öğrencilerden anlama sorularına gelen cevaplar araştırmacılar tarafından okunarak puanlanmıştır. Her öğrencin kitaplardan aldıkları puanlar ortaya çıkarılmış ve tablo haline getirilmiştir. Sonrasında ise ilgili çıkarımsal istatistikler gerçekleştirilmiştir (araştırmanın 4. ve 5. sorusu). Anlama sorularının analizinde Jamovi programı kullanılarak Friedman ve Mann-Whitney U analizleri gerçekleştirilmiştir. 


\section{Araştırma Etiği}

Araştırmaya başlamadan önce araştırmaya katılacak velilerin izinleri alınmıştır. Bu süreçte öncelikle Google formlar üzerinden veli onam formu hazırlanarak velilerden bu formu doldurmaları istenmiştir. Forma gelen cevaplarda araştırmaya katılmak istediğini belirten veliler ve bu velilerin öğrencileri belirlenmiştir. Gerekli başvuruların ardından Düzce Üniversitesi Bilimsel Araştırma ve Yayın Kurulu tarafından 25.06.2020 tarihli 2020/134 sayılı kararla oy birliği ile araştırmanın etik kurul onayı verilmiştir.

\section{Araştırmanın Güvenirliliği}

Öğrenci ebeveynlerinin görüşlerinden elde edilen bulgular, doğrudan alıntılarla desteklenmiştir. Doğrudan alıntılar ilgili tablolar altında bulgulardan sonra sunulmuştur. Veli için "V" kısaltması kullanılmış, kaçıncı veli olduğu ise rakamlarla ifade edilmiştir. Yine ebeveyn görüşlerinden ulaşılan bulgular ebeveynlere gösterilerek katılımc1 teyidi sağlanmıştır. Araştırma süreci tüm detayları ile verilerek araştırmanın transfer edilebilirliği artırılmıştır. Öğrenci ebeveynlerinin görüşleri farklı araştırmacılar tarafindan analiz edilmiş ve yapılan analizler bir araya getirilerek ortak kodlara ulaşılmaya çalışılmıştır. Böylelikle eş denetleme sağlanmıştır.

\section{Bulgular}

Araştırmanın verileri analiz edilerek bulgular hâline getirilmiştir. Bulgular kısmında salgın sürecinde öğrenci-ebeveyn etkileşimi, öğrenci ve ebeveynlerin kitaplara karşı tepkilerine yönelik betimsel analizler ve öğrenci anlama puanları yer almaktadır. Aşağıda ilk olarak öğrenci velilerinin çocuklarıyla ev ortamında gerçekleştirmiş oldukları akademik faaliyetlere ilişkin görüşlerine yer verilmiştir.

Tablo 1

Salgın Sürecinde Öğrencilerin Ev Ortamında Gerçekleştirdikleri Akademik Faaliyetler

\begin{tabular}{lc}
\multicolumn{1}{c}{ Faaliyetler } & $f$ \\
\hline Kitap okumak & 26 \\
Ödev yapmak & 21 \\
Eğitsel etkinlikler gerçekleştirmek & 18 \\
Ders çalışmak & 11 \\
Uzaktan eğitime katılmak & 9 \\
Araştırma yapmak & 2 \\
Deney yapmak & 1
\end{tabular}

Tablo 1'e bakıldığında öğrencilerin salgın sürecinde kitap okudukları, ödev yaptıkları ve çeşitli eğitsel etkinlikler gerçekleştirildikleri görülmektedir. Aynı zamanda öğrenciler ders çalışarak ve uzaktan eğitim faaliyetlerine katılarak salgın sürecini geçirmektedir. Bunlara ilaveten bazı veliler öğrencilerin araştırma faaliyetlerinde bulunduklarını ve deney yaptıklarını da belirtmiştir.

V5: EBA dersleri ve canlı dersleri oluyor. Ö̆gretmenin verdiği ödevleri Sevcan Ö̆gretmenin gönderdiği etkinlikleri yapıyor. Kalan zamanda oyun oynuyor, bazen bana yardım ediyor. Akşamları ailecek film günlerimiz oluyor, kutu oyunları oynuyoruz ya da oturduğumuz yer şehir dışında olduğu için yürüyüşe çıkıyoruz.

V20: Kendilerini ifade etmelerini destekleyici oyunlar oynuyoruz. Günlük hayatta ya da okuduğu kitaplarda anlamını bilmediği kelimelerle, deyimlerle karşılaştığında, anlamını araştırma ve bu kelime üzerinde konuşmalar yaparak kelime dağarcığını geliştirmeye çalışıyoruz. Merak ettiği konuları araştırması konusunda teşvik ediyor ve destekliyoruz. 
K6: Ders çalışıyoruz. Sonra ailecek oyunlar körebe, saklambaç, oynayıp evde iyi vakit geçirmeye çalışıyoruz.

Tablo 2'de salgın sürecinde öğrencilerin sanatsal, sportif ve sosyal faaliyetleri yer almaktadır;

Tablo 2

Salgın Sürecinde Öğrencilerin Sanatsal, Sportif ve Sosyal Faaliyetleri

\begin{tabular}{ll}
\multicolumn{1}{c}{ Faaliyetler } & $\mathrm{f}$ \\
\hline Kâğıttan tasarım yapmak & 6 \\
Tarımsal faaliyette bulunmak & 5 \\
Resim yapmak & 4 \\
Dans etmek & 3 \\
Müzik dinlemek & 2 \\
Spor yapmak & 2 \\
Bahçede vakit geçirmek & 2 \\
Bisiklete binmek & 2 \\
Şiir ezberlemek & 1 \\
Arkadaşlarıyla iletişime geçmek & 1 \\
Bilgisayar oynamak & 1 \\
\hline
\end{tabular}

Katılımcıların görüşleri incelendiğinde öğrencilerin salgın sürecinde çeşitli faaliyetlerle zaman geçirdiği ortaya çıkmaktadır. Sanatsal, sportif ve sosyal faaliyetler olarak ele alındığında öğrencilerin kâğıttan tasarımlar yaptı̆̆ı, tarımsal faaliyetlerde bulunduğu, resim yapma, dans etme gibi birçok faaliyet gerçekleştirdiği tablodan görülmektedir.

V5: Hikâyeler ve devamında hikâyeyle ilgili sorular olan bir kitabımız var onu yapıyoruz, beraber şiir ezberliyoruz, origami yapıyoruz, bazen klzım evin farkl yerlerine ödüller koyup bize içinde bilmeceler olan harita hazırlyyor kendisi bu tarz oyunlar üretiyor.

V2: Site içerisinde olduğumuz için genellikle site bahçesinde vakit geçiriyor benim çocuğum. Bisiklete binmek top oynamak gibi aktivitelerle zaman geçiyor. Ev içerisinde mutfakta vakit geçiririz kek yapmak, yemek yapımına yardım ile ilgilenir. Telefon, pc, tv den uzak olması için bunu teşvik ediyorum. Akşamları çocuğumuzla sinema saati yaparak birlikte onun yaşına uygun filmleri izleyip hem kritik yapıyoruz hem sakinleşiyoruz. Uyku öncesi kitap okuyarak günü bitiriyoruz. Uyku saatlerimiz değişti tabi.

Tablo 3'de veli ve öğrencilerin salgın sürecinde birlikte yaptıkları faaliyetlere yer verilmiştir;

Tablo 3

Veli ve Öğrencinin Salgın Sürecinde Birlikte Yaptıkları Faaliyetler

\begin{tabular}{lc}
\multicolumn{1}{c}{ Faaliyetler } & $f$ \\
\hline Oyun oynamak & 31 \\
Televizyon programı, film ve belgesel izlemek & 15 \\
Yiyecek içecek hazırlamak & 14 \\
Sohbet etmek & 13 \\
Ev işleri yapmak & 10 \\
Sokağa çıkmak & 3 \\
\hline
\end{tabular}

Tablo incelendiğinde veliler ve öğrencilerin birlikte oyunlar oynama, film izleme gibi aktiviteler gerçekleştirdikleri görülmektedir. Bu durumun yanı sıra veliler öğrencilerin sorumluluk bilincini geliştirmek için yiyecek içecek hazırlama, ev işlerini birlikte yapma gibi etkinlikleri öğrencilerle birlikte gerçekleştirdiklerini aktarmışlardır.

V3: Kitap okuduk, eğitici oyunlar oynadık, ailecek filmler izledik ve çiçek ektik.

V21: Bahçe etkinlikleri, ev içerisinde çadır kurma, minderlerle parkur yapma gibi oyunlar oynanır... Lego en sevilen oyuncak setimiz. Kitap okuma süremiz kısa. Bunun dişında ödevler ve online dersler...Birde mutfak faaliyetleri... 
V17: Okuduğumuzu anlama çalışmast yapıyoruz. Bahçemizde bitki yetiştiriyoruz ve dans ediyoruz.

Tablo 4'de salgın sürecinde öğrencilere sağlanan desteğe ilişkin velilerin hisleri yer almaktadır;

Tablo 4

Salgın Sürecinde Öğrencilere Să̆lanan Desteğe İlişkin Velilerin Hissettikleri

\begin{tabular}{ll}
\hline \multicolumn{1}{c}{ Veli Düşünceleri } & $f$ \\
\hline Mutlu olmak & 9 \\
Birlikte vakit geçirmekten hoşlanmak & 8 \\
Öğrenciyle çalışırken eğlenmek & 7 \\
Kendini sorumlu hissetmek & 7 \\
Planlı çalışmak & 3 \\
Stresli hissetmek & 2 \\
\hline
\end{tabular}

Tablo 4'e bakıldığında katılımcıların salgın sürecinde öğrenciye destek olurken yaşananlarda olumlu hislerin yoğunluğu dikkat çekmektedir. Mutluluk, keyifli vakit geçirme, eğlenmek gibi hislerin yanı sıra katılımcıların bu süreçte kendilerini sorumlu hissettiği ve stres altında olduklarını düşündükleri görülmüştür.

V17: Bugünlerde çocuğumla birbirimizi daha iyi tanıdığımızı hissediyorum. Tabi ki öncelikle uzaktan eğitimi takip ediyoruz. Birbirimize kitap okuyoruz, belgeseller izliyoruz.

V4: Çocuğumu yanıma alp onunla zaman geçirmek beni çok mutlu etti. Bunun ikimizin sorumluluğu olduğunu anlattım ona.

V23: Biraz sıkıcı, biraz eğlenceli, resmen evimiz bir okul, bir park, bir saha klsmen her şey o evin içinde. Yine de güzel să̆llk olsun.

Tablo 5'de salgın sürecinde velilerin yaşadıklarını ifade ettikleri zorluklar aktarılmıştır;

Tablo 5

Salgin sürecinde velilerin yaşadiklarl zorluklar

\begin{tabular}{lc}
\multicolumn{1}{c}{ Zorluklar } & $f$ \\
\hline Öğrenciye vakit ayıramamak & 11 \\
Öğrencinin ders çalışmak istememesi & 4 \\
Eğitimde yeterli olmamak & 3 \\
Salgın sürecinde sıkılmak & 3 \\
Eğitimsel faaliyetleri zenginleştirememek & 2 \\
Salgın sürecinde yorulmak & 2 \\
TV programlarından öğrencinin etkilenmesi & 1 \\
\hline
\end{tabular}

Tablo 5 incelendiğinde salgın sürecinde veliler en çok öğrenciye yeterli vakit ayıramamayı sorun olarak gördüklerini aktarmışlardır. Öğrencinin ders çalışmak istememesi, velilerin eğitim faaliyetlerinde kendilerini yeterli görmemeleri ve bu faaliyetleri zenginleştirecek kaynaklara sahip olmamaları süreçte yaşanan önemli zorluklar olarak ortaya çıkmıştır. Bunlara ek olarak katılımcılar salgın sürecinin sıkıcı ve yorucu olduğuna dikkat çekmişlerdir.

V7: Yaşadığımız bu süreç de anne baba olarak bizler çalışıyoruz. Evde geçirdiğimiz süre sadece ev ödevleri ve konu tekrarları ile geçmekte. Ailecek birlikte geçirebildiğimiz zaman çok kısıtlı. Zaman kalırsa güzel bir film seçip izliyoruz.

V23: Beni zorlayan şey ders yapmayl sevmeyişi onu ders konusunda uyarmam beni zorluyor.

V2: Etkilenmesin diye haber, televizyon izlemiyoruz. Normal hayat devam ediyor. Çok başaramazsak da günlük rutin tutmaya çalışıyoruz.

V10: Elimizde olan etkinlik malzemelerinin haricinde dışarı çıkıp alamadığımız için yapacaklarımız kisitliydl. 
Tablo 6'da araştırma sürecinde kullanılan kitaplara ve araştıramaya yönelik velilerin görüşleri yer almaktadır;

Tablo 6

Araştırma sürecinde kullanılan kitaplara ve araştırmaya yönelik veli görüşleri

\begin{tabular}{lc}
\hline \multicolumn{1}{c}{ Görüşler } & $f$ \\
\hline Kaliteli vakit geçirmek & 20 \\
Kitap okurken keyif almak & 12 \\
Bu tarz çalışmaları desteklemek & 6 \\
Kullanılan kitaplara yönelik eleştirilerde bulunmak & 5 \\
\hline
\end{tabular}

Tablo 6 incelendiğinde katılımcıların araştırma sürecinde yapılan okumalarla kaliteli vakit geçirdiklerini, kitap okuma sürecinde eğlendiklerini belirttikleri görülmektedir. Aynı zamanda katılımcıların benzer araştırmaların yapılması gerektiğine yönelik görüşleri de bulunmaktadır. Bazı katılımcılar ise araştırma sürecinde kullanılan resimli çocuk kitaplarının dil ve anlatım özelliklerinden kaynaklanan anlama zorluklarına yönelik görüşler belirtmişlerdir.

V10: Okumayı ögrendikten sonra kitapların kendi okuyan kızıma kitap okuduğumda eski zamanlara döndük. Onun okuma yazma bilmediği sadece bizi dinleyerek hayal gücünü harekete geçirdiği zamanları tekrar yaşadık. Slk sık tekrarlamak lazım. Kızım mutlu oldukça biz de mutlu olduk.

V16: böyle bir çalışma yaptığını için psikolojimizi zorlayan bu dönemde ebeveyni ve çocuğu bir araya getirdiğiniz bu etkinlik için size çok teşekkür ediyoruz. SEVGILER :)

V18: Ülkemizde üstün yetenekli çocuklara yönelik araştırma ve Türkçe kaynağın yeterli olmadığını düşünüyorum. Bu alanda bir çalışmanın yapılması ve bizim de bu çalışmanın içinde yer almamız beni mutlu etti ve umudumu yeşertti.

V17: Okumak güzeldi ancak resimlere anlam yüklemek ve yazısız resimleri yorumlamak zordu. Kitap seçimleri daha güzel yapılabilirdi. Kitapların seviyeleri özellikle dil kullanımı çok zayıftı.

Tablo 7'de salgın sürecinde velilerin öğretmenler ile ilgili görüşleri yer almaktadır;

Tablo 7

Salgın sürecinde velilerin öğretmenler ile ilgili görüşleri

\begin{tabular}{cc}
\hline Görüşler & $\mathrm{f}$ \\
\hline Öğretmene teşekkür etmek & 8 \\
Öğretmenlere yönelik olumlu tutum geliştirmek & 5 \\
\hline
\end{tabular}

Tablo 7 de velilerin salgın sürecinde öğretmenlere yönelik görüşlerine yer verilmiştir. Veliler ilgilerinden ve çabalarından ötürü öğretmenlere teşekkürünü iletirken, öğretmenlere olan saygılarının arttığına yönelik görüş belirtmişlerdir. Süreç içerisinde öğretmenlere yönelik herhangi bir olumsuz görüş belirtilmemiştir.

V5: Bu süreçte çocuğumun, etkinlikler aracıllğg ile ögretmeniyle iletişim halinde olmasl, okul ortamından kopmaması çok güzel. Yaptığı her etkinlikte öğretmeninden aldı̆̆ı küçük bir tebrik mesajı da çok hoşuna gidiyor ve moralini yükseltiyor.

V23: Açıkçası ögretmenlere daha fazla saygı duymaya başladım. Çocuklarla ilgilenmek bir özveri istiyor. Biz evde yeterliyiz, eğitimde yeterli olmadı̆̆ımızı düşünüyorum.

\section{Öğrencilerin metinlere yönelik tepkileri}

Tablo 8'de öğrencilerin "Düğünde, Yumurta Kırılırsa, Şanssız Balıkçılar" kitaplarına verdikleri cevapların dağılımları yer almaktadır.

Tablo incelendiğinde toplam cevapların \%70'ini okur merkezli cevapların oluşturduğu görülmektedir. Okur merkezli cevaplar içerisinde en çok kişisel tepkilere yer verildiği, öğrencilerin hikâyedeki olaylara katılmaya yönelik cevaplarının yüksekliği görülmektedir. Metin merkezli cevaplara bakıldığında toplam cevap sayısının \%30unu oluşturduğu ve bu kategoriden sadece Karakteri anlama ve Ana fikir başlıklarında cevaplar verildiği ortaya çıkmaktadır. 
Tablo 8

Öğrencilerin "Düğ̈̈nde, Yumurta Kırılırsa, Şanssız Balıkçılar" kitaplarına verdikleri cevapların dağllımları

\begin{tabular}{lll}
\hline Seri Metinler & $\mathbf{N}$ & $\mathbf{\%}$ \\
\hline Metin merkezli cevaplar & $\mathbf{2 8}$ & $\mathbf{3 0}$ \\
Hikâyeyi yeniden anlatma & - & - \\
Karakterleri anlama & 8 & 28.57 \\
Soru sorma & - & - \\
Tahmin etme & - & - \\
Ana fikir & 20 & 71.43 \\
Okur merkezli cevaplar & $\mathbf{6 4}$ & $\mathbf{7 0}$ \\
Kişisel tepki (düşünceler ve hisler) & 25 & 39.06 \\
Hikâye ile deneyimleri arasında bağlantı kurma & 15 & 23.44 \\
Hikâyedeki olaylara katılma isteği & 24 & 37.50 \\
Toplam & $\mathbf{9 2}$ & $\mathbf{1 0 0}$ \\
\hline
\end{tabular}

\section{Karakteri anlama}

Ö8: Bende yumurtamı iyi saklardım. Balık ekmek güzel bir yemek. Balık tutarken sabırlı olurdum.

Ana fikir

Ö21: Bazı şeyleri zamanında yapmazsan daha sonra olumsuz durumlarla karşılaşabilirsin, sorumluluklarımızı zamanında yerine getirmeliyiz.

Ö10. Dikkatli olmak, özenli olmak ve tecrübeli olmak mesajlarını veriyor.

\section{Kişisel Tepki}

Ö20. Kendimi onların yerine koydum ve bazen endişelendim, bazen heyecanlandım. Benim başıma da gelebilir diye düşündüm.

\section{Hikâyedeki olaylarla deneyimleri arasında bağlantı kurma}

Ö16: Şansız balıkçlları dinlerken bizimde abim ve babamla beraber balık tutmaya gideriz onları hatırladım, şimdi gidemiyoruz bi an önce o günlerin gelmesini istiyorum.

Ö17: Evet var. Ben anasinıfindayken yumurta boyayıp bir hafta boyunca okula götürmüştüm. Yumurtama gözüm gibi bakıyordum. Ama ilk gün bizim sinıfta olan çok yaramaz bir arkadaşım bana bilerek çelme taktı ve düşüm. Öğretmen olanlart gördü ve bana bir şans daha verdi. Tekrardan bir yumurta boyadim ve bir hafta kırmadan taşıdım.

\section{Hikâyedeki olaylara katılma isteği}

Ö6: Kerem yerinde olsaydım; hazine avına çıkardı. Mutlu olmasını ve umudunu kaybetmemesini isterdim.

Tablo 9'da Öğrencilerin "Flatsom” kitabına verdikleri cevapların dağılımlarına yer verilmiştir;

Tablo 9

Öğrencilerin "Flatsom” kitabına verdikleri cevapların dağılımları

\begin{tabular}{lcc}
\hline Flatsom & N & \% \\
\hline Metin merkezli cevaplar & $\mathbf{1 6}$ & $\mathbf{2 0 . 5 1}$ \\
Hikâyeyi yeniden anlatma & 1 & 6.25 \\
Karakterleri anlama & 1 & 6.25 \\
Soru sorma & - & - \\
Tahmin etme & 2 & 12.50 \\
Ana fikir & 12 & 75.00 \\
Okur merkezli cevaplar & $\mathbf{6 2}$ & $\mathbf{7 9 . 4 9}$ \\
Kişisel tepki (düşünceler ve hisler) & 31 & 50.00 \\
Hikâye ile deneyimleri arasinda bağlantı kurma & 10 & 16.13 \\
Hikâyedeki olaylara katılma isteği & 21 & 33.87 \\
Toplam & $\mathbf{7 8}$ & $\mathbf{1 0 0}$ \\
\hline
\end{tabular}

Öğrencilerin Flatsom kitabına verdikleri cevapların dağılımına bakıldığında toplam 78 cevap verildiği bu cevapların 16 tanesinin metin merkezli 62 tanesinin okur merkezli olduğu görülmektedir. $\mathrm{Bu}$ 
durumda öğrenci cevaplarının \%79.49 gibi bir çoğunluğunun okur merkezli cevaplardan oluştuğu ortaya çıkmaktadır. Metin merkezli cevaplar içeresinde Ana fikir başlığına gelen cevapların yoğunluğu görülmekte, aynı zamanda tahmin etme, hikâyeyi yeniden anlatma, karakterleri anlama başlığından da cevaplar bulunmaktadır. Öğrencilerin okur merkezli verdikleri cevaplar incelendiğinde cevapların \%50 sinin kişisel tepkilerden oluştuğu, \%16.61'inin hikâye ile deneyimler arasında bağlantı kurmaya yönelik cevaplar olduğu ve son olarak hikâyedeki olaylara katılma isteğine yönelik cevapların \%33.87 olduğu görülmektedir.

\section{Hikâyeyi yeniden anlatma}

Ö11: Fotoğraf makinesinin denize atılarak çocuklardan çocuklara geçmesi.

\section{Tahmin etme}

Ö20: Bizim bilmediğimiz, farklı deniz canlılarl olabilir.

\section{Ana fikir}

Ö18: Merakli olmak, incelemek ve araştırmak

\section{Kişisel Tepki}

Ö4: Hikâye çok ilgimi çekti. Ben bulsaydım çok heyecanlanır ve şaşırııdım

Hikâye ile deneyimleri arasında bağlantı kurma

Ö12: Yazın dedemlerin yazlığının oradaki sahilde midye bulmuştum. Hayatımda ilk defa böyle bir şey gördügüm için çok heyecanlanmıştım. Ama içini açıp baktığımda midem bulanmıştı. Çünkü içinde tuhaf bir canlı vardl ve korkmuştum.

\section{Hikâyedeki olaylara katılma isteği}

Ö15: Pilotsam kitabındaki fotoğraf makinesini bulan çocuk olmak isterdim atan çocuğun yerinde olsam, fotoğraf makinesini tekrar denize atmak yerine çöpe atardım...

Tablo 10'da Öğrencilerin "Voices in the park" kitabına verdikleri cevapların dağılımları aktarılmıştır;

Tablo 10

Ögrencilerin "Voices in the park" kitabina verdikleri cevapların dağılımları

\begin{tabular}{lll}
\hline Voices in the Park & N & \% \\
\hline Metin merkezli cevaplar & $\mathbf{1 6}$ & $\mathbf{1 9 . 7 5}$ \\
Hikâyeyi yeniden anlatma & - & - \\
Karakterleri anlama & - & - \\
Soru sorma & - & - \\
Tahmin etme & - & - \\
Ana fikir & 16 & 100 \\
Okur merkezli cevaplar & $\mathbf{6 5}$ & $\mathbf{8 0 . 2 5}$ \\
Kişisel tepki (düşünceler ve hisler) & 28 & 43.08 \\
Hikâye ile deneyimleri arasında bağlantı kurma & 13 & 20.00 \\
Hikâyedeki olaylara katılma isteği & 24 & 36.92 \\
Toplam & $\mathbf{8 1}$ & $\mathbf{1 0 0}$ \\
\hline
\end{tabular}

Tablo 10'a bakıldığında Voices in the Park metnine gelen cevapların \%80.25'inin okur merkezli cevaplardan, \%19.25'inin metin merkezli cevaplardan oluştuğu görülmektedir. Metin merkezli cevapların tamamının Ana fikir başlığında toplandığı, okur merkezli cevapların ise farklı dağılımlar gösterdiği tablodan anlaşılmaktadır. Okur merkezli cevaplar kişisel tepkiler \%43.08, hikâyedeki olaylara katılma isteği \%36.92 ve hikâye ve deneyimleri arasında bağlantı kurma \%20.00 şeklindedir.

\section{Ana fikir}

Ö18: Büyüklerimin sözünü dinleyip yanlarından uzaklaşmamak

\section{Kişisel Tepki}

Ö16: Parktaki sesler kitabını dinlerken çok şaşırdım ve heyecanlandım.

Hikâye ile deneyimleri arasında bağlantı kurma

Ö19: Bu kitap bana gittiğim hayvanat bahçesini hatırlattı. Bir de hep bir köpeğim olsun istiyorum onu hayal ettim.

\section{Hikâyedeki olaylara katılma isteği}

Ö16: Ben Smudge'nin yerinde olup Charles ile dondurma yemek isterdim.

Velilerin metinlere yönelik tepkileri 
Tablo 11 Velilerin "Dügünde, Yumurta Kırılırsa, Şanssız Balıkçılar" kitaplarına verdikleri cevapların dağılımları yer almaktadır;

Tablo 11

Velilerin "Dügünde, Yumurta Kırılırsa, Şanssız Balıkçılar” kitaplarına verdikleri cevapların dă̆llımları

\begin{tabular}{lll}
\hline Seri Metinler & N & \% \\
\hline Metin merkezli cevaplar & $\mathbf{2 7}$ & $\mathbf{2 8 . 7 2}$ \\
Hikâyeyi yeniden anlatma & - & - \\
Karakterleri anlama & 8 & 29.63 \\
Soru sorma & - & - \\
Tahmin etme & - & - \\
Ana fikir & 19 & 70.37 \\
Okur merkezli cevaplar & $\mathbf{6 7}$ & $\mathbf{7 1 . 2 8}$ \\
Kişisel tepki (düşünceler ve & 28 & 41.79 \\
hisler) & 21 & 31.34 \\
$\begin{array}{l}\text { Hikâye ile deneyimleri } \\
\text { arasında bağlantı kurma }\end{array}$ & & 26.87 \\
$\begin{array}{l}\text { Hikâyedeki olaylara katılma } \\
\text { isteği }\end{array}$ & 18 & $\mathbf{1 0 0}$ \\
Toplam & $\mathbf{9 4}$ &
\end{tabular}

Tablo 11' e göre velilerin seri metinlere yönelik yanıtlarının \%71.28' i okur merkezli iken \%28.72'si metin merkezli yanıtlar olarak ortaya çıkmıştır. Metin merkezli yanıtların \%70'i Ana fikir başlığ altındayken \%29.63'ü karakterleri anlamaya yöneliktir. Okur merkezli yanıtlarda \%41.79 Kişisel tepki belirtme, \%31.34 hikâye ve deneyimler arasında bağlantı kurma, \%26.87 ise hikâyedeki olaylara katılma isteğine yöneliktir.

\section{Karakteri anlama}

V1: Zeynep hayata olumlu bir karakterdi.

\section{Ana fikir}

V8: Bir şeyi elde etmek istiyorsak asla vazgeçmemeliyiz.

\section{Kişisel Tepki}

V7: Keyifli hikâyelerdi düğ̈̈n çok heyecanliydı yetişip yetişemeyecekleri merak konusuydu bir de balık tutabilecekler miydi yumurta sağlam kalabilecek miydi merak uyandıran hikâyeler.

\section{Hikâye ile deneyimleri arasında bağlantı kurma}

V5: Bir keresinde ailecek Bursa ya gezmeye gittiğimizde ne yiyeceğimize karar verememiștik. Uzun süre dolaştıktan sonra yemek yiyeceğimiz yere karar verebildik ve çok acıkmıştık. Düğünde kitabı bana bunu haturlatt.

Tablo 12 de Velilerin "Flatsom" kitabına verdikleri cevapların dağılımları görülmektedir;

Tablo 12

Velilerin "Flatsom" kitabına verdikleri cevapların dağılımları

\begin{tabular}{lll}
\hline Flatsom & N & \% \\
\hline Metin merkezli cevaplar & $\mathbf{1 3}$ & $\mathbf{1 6 . 6 7}$ \\
Hikâyeyi yeniden anlatma & & \\
Karakterleri anlama & 3 & 23.08 \\
Soru sorma & - & - \\
Tahmin etme & 2 & 15.38 \\
Ana fikir & 8 & 61.54 \\
Okur merkezli cevaplar & $\mathbf{6 5}$ & $\mathbf{8 3 . 3 3}$ \\
Kişisel tepki (düşünceler ve hisler) & 32 & 49.23 \\
Hikâye ile deneyimleri arasında bağlantı kurma & 14 & 21.54 \\
Hikâyedeki olaylara katılma isteği & 19 & 29.23 \\
Toplam & $\mathbf{7 8}$ & $\mathbf{1 0 0}$ \\
\hline
\end{tabular}


Velilerin Flatsom kitabına verdikleri yanıtlar incelendiğinde toplam cevap sayısının 78 olduğu görülmektedir. Bu cevapların \%83.33'ü okur merkezli cevaplardan oluşurken, cevapların \%16.67 si metin merkezli cevaplardır. Metin merkezli cevapların \%61.54'ü ana fikir başlığına yönelik cevaplarken, karakteri anlama ve tahmin etme bölümünden de cevaplar yer almaktadır. Okur merkezli cevaplar incelendiğinde cevapların \%49.23'ü kişisel tepkiler \%21.51'ü hikâye ile deneyimler arasında bağlantı kurma ve son olarak \%29.23'ü hikâyedeki olaylara katılma isteğine yönelik cevaplardan oluştuğu ortaya çıkmaktadır.

Karakteri anlama

V23: Bence güzel olan her varlı̆̆ı gözlemlemek onları bir sayfada toplamak atmaktan daha faydalı olur. Ana fikir

V7: Merak etmek araştırmak ve geleneği devam ettirmek.

Kişisel Tepki

\section{Hikâye ile deneyimleri arasında bağlantı kurma}

V12: Kitapta çocuk fotoğrafinı çekip makineye denize atması ve başkasının bunu bulup devam etmesi bana benzer bir olayı hatırlattı. Ben de üniversitedeyken arkadaşlarımla okuduğumuz kitapları ad tarih yazarak kitabı bitirdiğimiz yere (park, metro, cafe... vs) bırakıyorduk ve içine de kitabı bitirince lütfen kamuya açık bir yerde sonunu okuyup orada bırakın ki başkası da okusun yazmıştık. Hatta bir keresinde elime 8 ay önce okunmuş bir kitap geçmişti içinde teşekkür notuyla o anı hiç unutamam.

Hikâyedeki olaylara katılma isteği

V10: Fotoğraf makinesini bulan çocuğun yerinde olup o fotoğraf makinesini bende incelemek isterdim. Tablo 13'de velilerin Voices in the park isimli kitaba verdikleri cevapların dağılımları yer almaktadır;

Tablo 13

Velilerin "Voices in the park" kitabina verdikleri cevapların dağgllımlart

\begin{tabular}{lll}
\hline Voices in the Park & N & \% \\
\hline Metin merkezli cevaplar & $\mathbf{2 6}$ & $\mathbf{3 3 . 7 7}$ \\
Hikâyeyi yeniden anlatma & 1 & 3.85 \\
Karakterleri anlama & 11 & 42.31 \\
Soru sorma & - & - \\
Tahmin etme & 2 & 7.69 \\
Ana fikir & 12 & 46.15 \\
Okur merkezli cevaplar & $\mathbf{5 1}$ & $\mathbf{6 6 . 2 3}$ \\
Kişisel tepki (düşünceler ve & 22 & 43.14 \\
hisler) & & \\
Hikâye ile deneyimleri & 11 & 21.57 \\
arasinda bağlantı kurma & & 35.29 \\
Hikâyedeki olaylara katılma & 18 & $\mathbf{1 0 0}$ \\
isteği & & \\
Toplam & $\mathbf{8 1}$ & \\
\hline
\end{tabular}

Tabloya göre kitaba gelen toplam yanıt sayısı 81dir. Cevapların \%66.23’ü okur merkezli cevaplardan oluşmaktadır. Okur merkezli cevaplar kendi içerisinde \%43.14 kişisel tepkiler, \%21.57 hikâye ile deneyimler arasında bağlantı kurma ve \%35.29 hikâyedeki olaylara katılma isteği şekliden dağıllım göstermektedir. Metin merkezli cevaplara bakıldığında 26 cevabın metin merkezli olduğu görülmektedir. Bu sayı toplam cevap sayısının \%33.77'sini ifade etmektedir. Metin merkezli cevaplara bakıldığında yoğun olarak ana fikir ve karakteri anlama başlıklarında cevaplar bulunmaktadır. Bunlara ek olarak hikâyeyi yeniden anlatma ve tahmin etme başlıklarında da cevaplar yer almaktadır.

Karakteri anlama

V6: Ben de anne olarak çocuğumu sürekli dış tehlikelerden ya da zarar verebilecek kişilerden uzak tutmak isterim.

\section{Tahmin etme}

V11: Aynı durumlar karşısında insanlar farklı tepkiler verebilirler, bu yaşadıkları olaylara veya ruh halleri ile ilgili olabilir. Örneğin iş arayan bir ebeveynseniz önceliğiniz köpeğinizle ya da çocuğunuzla iletişim kurmaktan veya onların kontrol edilmesinden çok iş bulmaya odaklanmak olabilir. 


\section{Ana fikir}

V20: Aile ortamı ve ebeveyn tutumları, çocukların hayatlarında, şu anda ve gelecekte derinden etkiler birakır.

\section{Kişisel tepki-Hikâyeyi yeniden anlatma}

V13: Bana üzgün hissettirdi. Güzel bir ortamda bulunup olumsuz şeyler düşünebilmek kötü. Charles in yerinde olsaydım çok üzülürdüm. Köpek bile özgür kalıyorken o bankta oturmak zorunda bırakıllyor. Annesi dış görünüşünden dolayı köpeğe bile önyargıyla yaklaşıyor...

\section{Hikâye ile deneyimleri arasında bağlantı kurma}

V11: Oğlum arkadaşıyla oynamayı çok istemesine rağmen arkadaşının evine gitmesine izin vermemiş sonra üzülmüşı̈̈m.

\section{Hikâyedeki olaylara katılma isteği}

V7: Charles in annesine yabancı çocuklarla diyalog kurmanın o kadar da kötü bir şey olmadiğını anlatmak isterdim.

\section{Öğrencilerin Metinlere Yönelik Anlama Puanları}

Tablo 14'te öğrencilerin anlama testlerinden elde etmiş oldukları toplam puanlara ilişkin betimsel istatistiklere yer verilmiştir;

Tablo 14

Öğrencilerin Anlama Testlerinden Elde Etmiş Oldukları Toplam Puanlara İlişkin Betimsel İstatistikler

\begin{tabular}{cccccccc}
\hline & $N$ & Min-Maks & Ortalama & SS & Çarpıklık & Basıklık & $W$ \\
\hline Dügünde & 23 & $5-10$ & 8.39 & 1.37 & -1.021 & .466 & $.861^{* * *}$ \\
Yumurta Kırılırsa & 23 & $6-10$ & 7.96 & 1.11 & .092 & -.468 & .927 \\
Şansız Balıkçlar & 23 & $5-10$ & 9.43 & 1.34 & -2.625 & 6.329 & $.495^{* * *}$ \\
Voices in the Park & 23 & $7-10$ & 9.17 & .98 & -1.005 & .078 & $.789^{* * *}$ \\
Flotsam & 23 & $4-10$ & 7.82 & 2.33 & -.716 & -1.076 & $.811^{* * *}$ \\
\hline$* * *$
\end{tabular}
$* * * p<.001$

Yukarıdaki tablo göz önünde bulundurulduğunda öğrencilerin anlama testlerinden elde etmiş oldukları toplam puanların normal bir dağılım göstermediği anlaşılmıştır[ $(W(23)=.861, p=.000),(W(23)=.927$, $p=.093),(W(23)=.495, p=.000),(W(23)=.789, p=.000),(W(23)=.811, p=.001)]$. Bunun yanında yapılan aykııı değer ve Box Plot analizleri anlamlı farklılık gösteren kişilerin veri setinde olmadığını göstermiştir. Box Plot (kutu diyagramı) analizi verinin gruplar arasındaki normal dağılımı göstermektedir. Kutu diyagramının farklı bölümleri arasındaki boşluklar verinin dağılım derecesini yani çarpıklığı ve aykırı değerleri göstermektedir. Dolayısı ile yapılan "kutu diyagram" analizi herhangi bir çarpıklık ve aykırı değer ortaya koymamıştır. Yine bu süreci destelemek amacı ile amacı ile Z-puan testi de gerçekleştirilmiş̧tir. Z-puan testi standart sapma değeri olarak da bilinir. Normal bir dağılımda bu değerin (herhangi bir puanın) $-3+3$ aralığına düşmesi beklenmektedir. Bu değerlerin dışında kalan puanlar normal dağılım için risk oluşturmaktadır. Anlamlı farklılık oluşturan herhangi bir puana rastlanılmamıştır. Yani öğrencilerin anlamayla ilgili başarı testlerinden elde etmiş̧ oldukları puanların her biri normal dağılım eğirişi içerisinde standart sapma göstermiştir. Merkezi dağglım ölçüleriyle ilgili yapılan analizler ve anlama testlerine yönelik elde edilen çarpıklık ve basıklık değerleri de veri setinin normal dağılımla ilgili problemler olduğunu göstermiştir. Bundan dolayı üstün yetenekli öğrencilerin okunan seri metinlerle ilgili anlama düzeylerinin farklılaşıp farklılaşmadığ 1 Friedman testi ile analiz edilmiştir. Bu analize ilişkin bulgular aşağıdaki tabloda sunulmuştur.

Tablo 15

Öğrencilerin Seri Kitaplara İlişkin Anlama Testlerinden Elde ettikleri Toplam Puanlara Yönelik Friedman Testi Sonuçları

\begin{tabular}{cccccccc}
\hline & $N$ & Ortalama & $S S$ & SiraOrtalamaları & $d f$ & $X^{2}$ & $p$ \\
\hline Düğünde & 23 & 8.39 & 1.37 & 1.76 & 2 & 19.108 & .000 \\
YumurtaKırılırsa & 23 & 7.96 & 1.11 & 1.54 & & & \\
ŞansızBalıkçılar & 23 & 9.43 & 1.34 & 2.70 & & & \\
\hline
\end{tabular}


Öğrencilerin seri metinlerle ilgili anlama testi ölçümleri arasında Friedman testi gerçekleştirilmiş ve analiz sonuçları Ki-Kare değerinin anlamlı farklılık gösterdiğini ortaya koymuştur $\left(X^{2}=19.108, p=\right.$ .000). Anlama testlerine ilişkin ortalamalar ve sıra ortalamaları göz önünde bulundurulduğunda öğrencilerin üçüncü anlama testinden elde ettikleri toplam puanların diğerleri ile karşılaştırıldığında daha iyi bir düzeyde ve yüksek olduğu ifade edilebilir. Öğrencilerin okunan bağımsız resimli çocuk kitapları (postmodern) anlama durumlarına ilişkin Mann-Whitney U testi sonuçları aşağıdaki tabloda sunulmuştur.

Tablo 16

Öğrencilerin Okunan Bağımsız Resimli Çocuk Kitaplarını Anlama Düzeylerine İlişkin Mann-Whitney U testi sonuçları

\begin{tabular}{cccccc}
\hline Grup & $N$ & Sira ortalamas1 & Sira Toplam1 & $U$ & $p$ \\
\hline Voices in the Park & 23 & 26.63 & 612.50 & \multirow{2}{*}{192.500} & .099 \\
Flotsam & 23 & 20.37 & 468.50 & \\
\hline
\end{tabular}

Tablo incelendiğinde Mann-Whitney U testi öğrencilerin "Voices in the Park" resimli çocuk kitabına ilişkin elde ettikleri anlama puanlarının sıra ortalamasının ( $M d n=26.63)$, öğrencilerin Flotsam resimli çocuk kitabına ilişkin elde ettikleri anlama puanlarının sıra ortalamasından $(M d n=20.37)$ yüksek olduğunu göstermiştir. Başka bir deyişle öğrenciler "Voices in the Park" kitabına ilişkin anlama sorularında daha yüksek performans sergilemişlerdir. Ancak test sonuçlarının anlamlı olmadığı da gözlemlenmiştir $(U=192.500, p=.099)$.

\section{Tartışma ve Sonuç}

Salgın nedeniyle eğitim ve öğretim faaliyetlerinin uzaktan gerçekleştirilmesi ev ortamının rutininin değişmesine neden olmuştur. Birçok faaliyet ev ortamında yürütülmeye başlanmıştır. Bu araştırmanın sonuçlarına göre salgın sürecinde veli ve öğrenciler akademik faaliyetler, sanatsal ve sportif faaliyetlerde birlikte vakit geçirmektedirler. Öğrencilerin akademik başarıları için ayırdıkları zamanda en sık olarak kitap okudukları ve ödev yaptıkları bulgularına ulaşılmıştır. Salgın sürecinde öğrencilerin sanatsal ve sportif faaliyetlerde de bulundukları sıklıkla ifade edilen bulgular arasındadır. Kâğıttan tasarım yapmak, tarımsal faaliyetlerde bulunmak, resim yapmak ve dans etmek sik ifade edilen görüşlerdir. Yıldız ve Bektaş (2021) salgın sürecinde velilerin çocuklarıyla birlikte resim yapma ve kitap okuma faaliyetlerinde bulundukları sonucuna ulaşmışlardır. Bu araştırmanın sonuçları ile Yıldız ve Bektaş'ın (2021) araştırmasının sonuçları birbirini destekler niteliktedir. Kitap okuyarak, sanatsal ve sportif faaliyetlerde bulunarak geçirilen zamanda salgının akademik ve sosyal etkilerini en aza indirmek amacı taşındığ 1 yorumu yapılabilir.

Araştırmanın sonuçlarında velilerin sık sık çocuklarla oyun oynayarak vakit geçirdikleri ortaya çıkmıştır. Ramazan vd. (2012) araştırmaları sonucunda çocuklarda yetersiz oyun ortamlarından kaynaklı olarak yaşayacakları sorunların önüne geçmek için çocuklara yeterli oyun imkânları sağlandığını aktarmaktadır. Mart ve Kesicioğlu (2020) salgın sürecinde velilerin ev ortamlarının oyun için yeterli olduğunu ifade ettiklerini aktarmakta; veliler, oyunların öğrencilerin sosyal ve duygusal gelişimleri için önemli olduğunu belirtmişelerdir. Aynı zamanda salgın sürecinde çocukların oyun oynama vakitlerinin arttığı görülmüştür. Bu durum bu araştırmanın sonuçlarıyla benzerlik taşımaktadır. Civelek ve Uyanık (2020) ise, salgın sürecinde oynanan oyunların çoğunun oyun niteliği taşımadığı, oyunların eskiye nazaran daha küçük gruplar arasında oynandığını belirtmektedir.

Araştırmanın sonuçlarına göre velilerin salgın sürecinde öğrencilere destek olurken mutlu oldukları, birlikte vakit geçirmekten keyif aldıkları ancak öğrenci ihtiyaçlarını karşılamada kendilerini sorumlu hissettikleri ve stres altında oldukları ortaya çıkmıştır. Velilerin yaşadıkları zorlukları sıralayacak olursak; öğrenciye vakit ayıramamak öğrenci eğitimi için yeterli bilgiye sahip olamamak ve öğrencinin ders çalışmaya isteksiz olması önemli sonuçlar arasındadır. Velilerin yaşadığı zorlukların altında yatan temel neden olarak çocuğun öğrenme kayıplarının önüne geçmek için yaşadıkları stres durumu gösterilebilir.

Araştırmanın sonuçlarına göre veli-öğrenci etkileşimine dayanarak evde okunan seri metinlere yönelik ögrencilerin tepkilerinin \%70'inin okur merkezli tepkiler olduğu görülmektedir. Aynı zamanda Flatsom ve Voices in the Park isimli resimli çocuk kitaplarına verilen tepkilerin yaklaşık \%80'i okur merkezli tepkilerden oluşmaktadır. Aynı kitaplara velilerin tepkileri de öğrenci tepkilerinden farklılaşmamaktadır. Velilerin seri metinler için tepkilerinin \%71'i okur merkezli tepkilerdir. Veliler 
Flatsom resimli çocuk kitabına \%83 oranında okur merkezli tepkiler ifade ederken, Voices in the Park resimli çocuk kitabı için bu oran \%66'dır. Bu araștırmanın sonuçlarına göre öğrenci ve veli etkileşimine dayalı gerçekleşen okumalarda hem seri metinlerde hem de resimli çocuk kitaplarına yönelik öğrenci ve velilerin tepkilerinin okur merkezli tepkiler olduğu görülmektedir. Aile katılımının tüm çocukların akademik başarıları üzerinde etkisi çok dikkat çekmektedir (Lindberg, 2017). Öğretmenlere göre de aile katılımı okuma yazma başarısını arttırmaktadır (Kıvrak ve Yıldırım, 2020). Öğrenci ve velilerin kitaplara yönelik benzer tepkileri okuma işleminin birlikte yapılmasıyla açıklanabilir. Connell'e (1996) göre okurlar, tepkilerinde kişisel yaşantıları ve edebi tecrübeleriyle anlamı şekillendirerek okur merkezli olarak metinle ilişki kurmalıdır. Bu çalışmaya benzer olarak son birkaç yıl içerisinde yapılan birçok araştırmada okur merkezli tepkilere ulaşıldığı görülmektedir (örn. Çevik ve Müldür, 2019; Kanık Uysal, Ateş, 2020; Karagöz, 2018; Kaya Tosun ve Doğan, 2020; Ulusoy, 2016; Yekeler ve Ulusoy, 2017). Peki okur merkezli tepkiler neyi ifade etmektedir? Okurlar, metne karşı kişisel duygu ve düşüncelerini yansıtarak metinde var olan olaylarla kendi deneyimlerini hayal güçlerinin yardımıyla birleştirecek; metinde yer alan olayların bir parçası olmak istediklerini ortaya koyacaklardır (Karagöz, 2018). Kitaplara verilen duygusal tepkiler, kitapta yer alan olaylara katılma isteği ve okurun kitapta kendi yaşantılarından izler bulması okurun düşünme becerileri, sosyal ve bilişsel gelişimi hakkında önemli bilgiler sağlayabilir (Yekeler ve Ulusoy, 2017). Rosenblatt (1995) okurlar metne kendi kişisel anlamını yüklemediği sürece metnin sayfadaki mürekkepten ibaret olduğunu belirtmektedir (akt. Kaya Tosun, 2018). Yine Rosenblatt (1999) "Edebi ürün düşük duygusal etkiye sahipse, tartışmanın hepsi boş laf kalabalığı olur" ifadesiyle okur tepkilerinin önemini vurgulamaktadır. Ailelerin öğrencilerin okuryazarlık faaliyetlerine katılımı çocukların okur yazarlık becerileri üzerinde önemli etkisi vardır (Sénéchal ve LeFevre, 2002). Bu araştırmada okur tepkilerinin \%70 hatta $\% 80$ a ulaşan okur merkezli yanıtlardan oluşmasında okumaların ev ortamında veli-öğrenci etkileşimine dayalı gerçekleştirilmesinin önemli etkilerinin olduğu düşünülmektedir. Çünkü okurun tepkilerinde okuma deneyimlerinin yanı sıra okuma ortamı da önemlidir (Rosenblat, 1978). Ateş ve Aktaş'a (2020) göre bu unsurlardan birinin değişmesi metne yönelik tepkileri etkileyebilmektedir.

$\mathrm{Bu}$ araştırma üstün yetenekli öğrencilerle yürütülmüştür ve bu öğrenciler iyi birer okuyucu olarak nitelendirilmektedir. Aynı zamanda resimli çocuk kitaplarına aşina oldukları bilinmektedir. Hem seri kitaplarda hem resimli çocuk kitaplarında okur merkezli yanıtların oranının yüksek olduğu sonucuna ulaşılmıştır. Ateş ve Aktaş (2020) estetik açıdan kitaplarla yeterli deneyimlere sahip olmayan öğrencilerle gerçekleştirdiklerini ifade ettikleri çalışmada okurların tepkilerinde metin ve okur merkezli tepkilerin birbirine yakın olduğu sonucuna ulaşmışlardır. Bu sonuçlardan yola çıkarak okuyucudan kaynaklanan ve kontrol altına alınması güç değişkenlerin okur tepkilerini etkilediği yorumu yapılabilir. Aynı zamanda Ateş ve Aktaş (2020) okuma ortamının da okur tepkilerini etkileyebileceğinden bahsetmektedir. Bu araştırmada veli-öğrenci etkileşimine dayalı evde gerçekleşen okumalar sonucunda farklı yaş gruplarına ait öğrenci ve velilerin okur merkezli tepkiler vermişlerdir.

Heller'a (2006) göre "Bu kitap kendi hayatınıda ne hatılatıyor?" sorusu anlama becerilerinin gelişmesine katkı sağlayabilmektedir (akt. Yekeler ve Ulusoy, 2017). Okur tepki kuramında anlam, okurun kişisel yaşantıları ile oluşturulmaktadır (Kaya Tosun, 2018). Ev ortamında veli-öğrenci etkileşimine dayalı okunan kitaplarda öğrencilerin seri kitaplarda ilk iki kitaba nazaran son kitabı daha iyi anladıkları sonucuna ulaşılmıştır. Lukens, Smith ve Coffel'e (2018) göre seri metinler genç okurlara okuma becerisi için güven verirler çünkü seri ilerledikçe akıcılık artar, kitaplardaki değişmezlik, tahmin edilebilirlik okurun yeni karakterler ve farklı konularda yaşayacağ 1 deneyimleri geciktirir. $\mathrm{Bu}$ araştırmada okurların serinin son kitabında daha yüksek anlama puanları aldığı görülmektedir. Bu bakımdan Lukens, Smith ve Coffel'ın (2018) görüşleriyle bu araştırmanın sonuçları benzerlik taşımaktadır. Öğrencilerin resimli çocuk kitaplarına yönelik anlama puanları arasında anlamlı bir fark olmadığı sonucuna ulaşılmışıı. Ancak azda olsa daha fazla okur merkezli tepki verilen kitabın anlama puanları diğer resimli çocuk kitabından yüksek olduğu gözlenmiştir. Bu bağlamda düşünüldüğünde okur tepkileri ve metinlerin anlaşılması arasında bir ilişkiden söz edilebilir. Bu araştırmada seri metinlerden tek bir başlıkta tepkilerin toplanması serinin her bir kitabına yönelik anlama puanları ve okur tepkilerinin karşılaştırılmasını kısıtlamıştır. Ancak öğrencilerin aşina olduğu seri metinlere yönelik tepkileri ve tepki düzeyleri ile anlama düzeylerinin karşılaştırıldığı çalışmalarla alan yazın zenginleştirilebilir.

Sonuç olarak bu araştırma salgın sürecinin neden olduğu öğrenme kayıpları bağlamında üstün zekalı öğrencilerin durumlarını, bu salgın sürecinde ev ortamında ebeveynleri ile gerçekleştirmiş oldukları 
etkinleri, kendilerine okunan kitaplara yönelik tepkilerini, aynı zamanda ebeveynlerin kitaplara yönelik tepkilerini ve salgın sürecinde ebeveyn-çocuk etkileşimini betimlemek amacı ile gerçekleştirilmiştir. Bu ve benzeri yapılacak çalışmalar salgın sürecinde eğitim bağlamında öğrencilerin durumlarının ortaya konulmasına ve gerekli önlemlerin alınmasına katkı sağlayacaktır.

\section{Kaynakça}

Ateş, S. ve Aktaş, N. (2020). Duygu durumlarının farklılaştığı resimli çocuk kitaplarına yönelik okuyucu tepkilerinin incelenmesi. Ahi Evran Üniversitesi Sosyal Bilimler Enstitüsü Dergisi, 6(3), 726745.https://doi.org/10.31592/aeusbed.742584

Baker, L. (2003). The role of parents in motivating struggling readers. Reading \& Writing Quarterly, 19, 87-106.https://doi.org/10.1080/10573560308207

Can, A., Deniz, E. ve Çeçen, M.(2016).Ortaokul öğrencilerinin okuma tutumları. Electronic Turkish Studies, 11(3).645-660.http://dx.doi.org/10.7827/TurkishStudies.9311

Clark, C and Picton, I. (2012). Family Matters: The Importance of Family Support for Young People's Reading. Findings from the National Literacy Trust's annual survey 2011. London: National Literacy Trust.

Connell, J. M. (1996). Assessing the influence of Dewey's epistemology on Rosenblatt's reader response theory. Educational Theory, 46(4), 395-413.https://doi.org/10.1111/j.17415446.1996.00395.x

Crosby, S. A., Rasinsky, T., Padak, N., ve Yildirim, K. (2015). A-3 year study of a school-based prantal involvement program in early literacy. The Journal of Educational Research, 108(2), 165-172, DOI: $10.1080 / 00220671.2013 .867472$

Çaykuş, E. T, ve Mutlu Çaykuş, T. (2020). Covid-19 pandemi sürecinde çocukların psikolojik dayanıklılığını güçlendirme yolları: Ailelere, öğretmenlere ve ruh sağlığı uzmanlarına öneriler. Avraysa Sosyal ve Ekonomi Araştırmaları Dergisi, 7(5), 95-113.

Çevik, A., \& Müldür, M. (2019). "Vapurları Seven Çocuk" adlı kitabın okur-tepki teorisi ile değerlendirilmesi. International Journal of Languages' Education and Teaching, 7(3), 4050.DOI: 10.29228/ijlet.23375

Galindo, C., ve Sheldon, S. B. (2012) School and home connections and children's kindergarten achievement gains: The mediating role of family involvement. Early Childhood Research Quarterly, 27, 90- 103. https://doi.org/10.1016/j.ecresq.2011.05.004

Er, Z. ve Arıcı, F. A. (2018). Ortaokul öğrencilerinin okuma becerilerinin geliştirilmesinde aile etkisi.Türkiye Eğitim Dergisi, $3(1), \quad 1-2$. https://dergipark.org.tr/tr/pub/turkegitimdergisi/issue/37897/390974 adresinden alınmıştır.

Epstein, J. L. (2011). School, family, and community partnerships: Preparing educators and improving schools (2nd ed.). Westview Press.https://doi.org/10.4324/9780429494673

Faires, J., Nichols, W. D., \& Rickelman, R. J. (2000). Effects of parental involvement in developing competent readers in first grade. Reading Psychology, 21(3), 195215.https://doi.org/10.1080/02702710050144340

Hancock, M. R. (2008). A celebration of literature and response: children, books, and teachers in $K-8$ classrooms (3rd. ed.). Upper Saddle River, New Jersey: Pearson.

He, F., Deng, Y., ve Li, W. (2020). Coronavirus disease 2019 (Covid-19): What we know? Journal of Medical Virology, 1-7.https://doi.org/10.1002/jmv.25766

Jeynes, W.H. (2005). A meta-analysis of the relation of parental involvement to urban elementary school student academic achievement. Urban Education, 40, 237269.https://doi.org/10.1177/0042085905274540

Jeynes, W.H. (2007). The relationship between parental involvement and urban secondary school student academic achievement: A meta-analysis. Urban Education, 42(1), 82110.https://doi.org/10.1177/0042085906293818

Jordan, G.E., Snow, C.E. and Porsche, M.V. (2000). Project EASE: The effect of a family literacy project on kindergarten students' early literacy skills. Reading Research Quarterly, 35, 524-546.

Kanık Uysal, P. ve Ateş, S. (2020). Okur-Tepki Teorisi: Küçük Kara Balık örneği. Ana Dili Eğitimi Dergisi, 8(3), 777- 796. DOI: 10.16916/aded.713103 
Karagöz, B. (2018). Ortaokul 5. sınıf öğrencilerinin resimli çocuk kitaplarına ilişkin tepkileri üzerine bir inceleme. Ana Dili Ë̆itimi Dergisi, 6(4), 1198-1218.https://doi.org/10.16916/aded.429948

Kaya Tosun, D. (2018). Okuma çemberlerinin okuduğunu anlama, akıcı okuma, okuma motivasyonu ve sosyal beceriler üzerindeki etkisi ve okur tepkilerinin belirlenmesi. (Yayınlanmamış Doktora Tezi). Pamukkale Üniversitesi, Denizli.

Kaya Tosun, D. ve Doğan, B. (2020). Okuma çemberlerinin Okuduğunu anlama ile akıcı okuma üzerindeki etkileri ve okur tepkileri: Bir karma yöntem araştırması. Eğiim ve Bilim, 45(203), 153-176. DOI: 10.15390/EB.2020.8716

Kaysılı, B. K. (2008). Akademik başarının arttırılmasında aile katılımı. Ankara Üniversitesi Eğitimbilimleri Fakültesi Özel Eğitim Dergisi, 83.https://doi.org/10.1501/Ozlegt_0000000115

Kıvrak, Z. ve Yıldırım, K. (2020). Öğretmenlerin gözünden birinci sınıf öğrencilerin okuma ve yazma becerilerini öğrenim süreçlerine ailelerin katılımı. Ana Dili Ĕgitimi Dergisi, 8(2), 447-468.

Linberg, E. N. (2017). Aile katılımı: bir kavramsal ve durumsal analiz çalışması. Uluslararası Eğitim Bilimleri Dergisi, 4(13), 51-72.

Lukens, R., J., Smith, J., J., ve Coffel, C., M. (2018). Çocuk edebiyatına eleştirel bir bakış (1. Baskı). Erdem Yayınları.

Mart, M. \& Kesicioglu, O.S. (2020). Parents' opinion to play at home during COVID-19 pandemic. Turkish Studies, 15(4), 945-958. https://dx.doi.org/10.7827/TurkishStudies. 44381

Merriam, S. B. (2009). Qualitative research: A guide to design and implementation:San Francisco: Jossey-Bass

Ramazan, O., Adak Ozdemir, A. ve Ozdemir Beceren, B. (2012). Evaluation of play from private and public pre-school children's point of view. Procedia: Social and Behavioral Sciences, 46, 2852 2856.DOI: $10.1016 / \mathrm{j}$. sbspro.2012.05.576

Rowe, K. (1991). The influence of reading activity at home on students' attitudes towards reading, classroom attentiveness and reading achievement: An application of structural equation modelling. British Journal of Educational Psychology, 61, 19-35.

Rosenblatt, L.M. (1978). The reader, the text, the poem: The transactional theory of the literary work. Carbondale: Southern Illinois University Press.

Rosenblatt, L. M. (1999). Literature as exploration. NY: The Modern Language Association of America.

Sénéchal, M. and LeFevre, J. (2002). Parental involvement in the development of children's reading skill: A five-year longitudinal study. Child Development, 73(2), 445-460.DOI: 10.1111/14678624.00417

Ulusoy, M. (2006). Resimli çocuk kitapları ve okur tepki teorisi. Illköğretim Online, 15(2), 487-497. doi: http://dx.doi.org/10.17051/io.2016.02208

UNESCO.(2020). Startling digital divides in distance learning emerge. UNESCO. https://en.unesco.org/news/startling-digital-divides-distance-learning-emerge

Van Steensel, R. (2006). Relations between socio-cultural factors, the home literacy environment and children's literacy development in the first years of primary education. Journal of Research in Reading, 29(4), 367-382.DOI: 10.1111/j.1467-9817.2006.00301.x

Yekeler, A., D., ve Ulusayo, M. (2017). İlkokul öğrencilerinin bilgi verici resimli çocuk kitaplarına yönelik tepkileri. Anadolu Kültürel Araştırmalar Dergisi, 1(2), 20-39.

Yıldız, S. ve Bektaş, F. (2021). COVID-19 salgınının çocukların boş zaman etkinliklerinde yarattığı değişimin ebeveyn görüşleriyle değerlendirilmesi. Gazi Beden Eğitimi ve Spor Bilimleri Dergisi, 26(1), 99-122.https://dergipark.org.tr/tr/pub/gbesbd/issue/59393/835694 den alınmıştır.

Yılmaz C. ve Çalışkan M.(2017). Yatılı ortaokul öğrencilerinin okuma motivasyonlarının incelenmesi.Turkish Studies, 12(33).573-588. http://dx.doi.org/10.7827/TurkishStudies.12541

WHO. (2020a). Coronavirus disease (COVID-19) Pandemic. World health Organization. https://www.who.int/emergencies/diseases/novel-coronavirus-2019

WHO. (2020b). WHO Coronavirus Disease (COVID-19) Dashboard. World health Organization. https://covid19.who.int/ 


\section{Extended Abstract}

\section{Introduction}

The new type of coronavirus disease that emerged in Wuhan, China in December 2019 was widely defined as coronavirus, with the name of the virus causing the disease as SARS-Cov-2 (She, Deng \& Lİ, 2020). The epidemic caused children to move away from their school status and start learning by distance education without taking part in any adaptation process before.

Although the achievements of the students at school before the distance education process were enriched with various activities at home, the work done at home became the only source of learning because there was no school education during the pandemic period (Çaykuş \& Mutlu Çaykuş, 2020). One of the areas that parents can easily get involved in is literacy. The parent involved in the process with a reading material will make a difference in the development of the child's literacy skills (Sénéchal \& LeFevre, 2002). It is known that reading activities at home have significant effects on reading success, reading attitude, reading motivation and language skills (Clark \& Picton, 2012). With the closure of schools and the start of the distance education period due to coronavirus epidemic, the importance of the activities carried out with the participation of the family in the home environment has once again become clear. In this research, it was aimed to reveal the activities carried out with parent-student interaction and the reactions developed against the books read based on parent-student interaction in the home environment during the epidemic process.

\section{Method}

The sample of the research consisted of 23 gifted students, 16 boys and 9 girls, and their parents. There are 3 serial children's books used in the research process. The postmodern picture children's books used in the process were written and illustrated by David Wiesner. In this process, books named "Flotsam" and "Voices in the Park" by David Wiesner were used. 4 different data collection tools were used to access the data of the research. In order to determine the effect of the epidemic process on the studentparent interaction, an epidemic process form was prepared by experts, students 'reactions to the picture children's books read were taken, and comprehension questions were used to reach students' comprehension scores. At the same time, a demographic information form was created to obtain demographic information of family and students. During the data analysis process, the responses to each data collection tool were analyzed separately by using descriptive analysis. The analyzes are tabulated and sample quotations are included. Parents were coded as "V" were and students as "Ö". In the analysis of reader reactions, the responses from the students were read one by one by the researchers. Students' answers were analyzed using the categories developed by Wollman-Bonilla and Werchadlo (1995). The frequency and percentages of the answers were calculated and made into tables. The answers to the comprehension questions from the students were scored by the researchers. The scores that each student got from the books were revealed and turned into a table. Subsequently, relevant inferential statistics were made.

\section{Findings, Result and Discussion}

The fact that education and training started to be carried out online instead of school buildings due to the epidemic, caused a change in the routine of the home environment.

Many activities have started to be carried out in the home environment. According to the results of this research, parent-student relationship during the epidemic process; it has been revealed that they spend time together in academic activities, artistic and sports activities.

It was found that the students mostly read books and did homework in the time they allocated for their academic success. According to the results of the study, it was revealed that the parents were happy while supporting students enjoyed spending time together, but felt responsible and under stress in meeting the needs of the students during the epidemic process. The difficulties experienced by the parents occurred in cases such as not being able to spare time for the student, not having enough information for student education, and the student being unwilling to study.

According to the results of this study, it is seen that the reactions of students and parents towards both serial texts and illustrated children's books are reader-centered reactions in readings based on student and parent interaction. Similar reactions of students and parents to the books can be explained by doing the reading process together. According to Connell (1996), readers should establish a reader-centered 
relationship with the text by shaping the meaning through their personal experiences and literary experiences in their reactions. Similar to this study, it is seen that reader-centered reactions have been reached in many studies conducted in the last few years (e.g. Çevik \& Müldür, 2019; Kanık Uysal, Ateş, 2020; Karagöz, 2018; Kaya Tosun \& Doğan, 2020; Ulusoy, 2016; Yekeler \& Ulusoy , 2017). It was concluded that in the books read based on parent-student interaction in the home environment, students understand the last book better than the first two books in serial books.

According to Lukens, Smith, and Coffel (2018), serial texts give young readers confidence in reading skills because as the series progresses, fluency increases, the stability and predictability of the books delay the reader's experiences with new characters and different subjects. In this study, it is seen that the readers got higher comprehension scores in the last book of the series. In this respect, the views of Lukens, Smith and Coffel (2018) are similar to the results of this study. It was concluded that there was no significant difference between the students' comprehension scores of the children's picturebook

*Yazarlar makaleye eşit oranda katkı sağlamış olduklarını beyan ederler.

** Düzce Üniversitesi Bilimsel Araştırma ve Yayın Kurulu tarafından 25.06.2020 tarihli 2020/134 sayılı kararla oy birliği ile araştırmanın etik kurul onayı verilmiştir. 